\title{
A Comprehensive Research on Empowerment and Service Recovery Performance at Five-Star Hotels in Jordan
}

\author{
Mousa Masadeh \\ Mukhles M. Al-Ababneh \\ Associate Professor \\ Department of Hotel and Tourism Management \\ Petra College for Tourism and Archaeology \\ Al-Hussein Bin Talal University \\ P. O. Box 20, Ma'an 71111 \\ Jordan
}

Samer M. Al-Sabi

Associate Professor

Business Administration Department, Business College

King Faisal University

P.O. Box 380, Al Ahsa 31982

Saudi Arabia

\begin{abstract}
The aim of this research is to provide a comprehensive picture on the relationships between empowerment and service recovery performance. A 51-item questionnaire, measuring empowerment and service recovery performance, was distributed to 425 employees working in five-star hotels in Jordan with a $70.1 \%$ of response rate. Principle component analysis was utilized to determine the construct structure for empowerment and service recovery performance as well as multiple regression analyses to determine the relationships between empowerment and service recovery performance. The results show that two perspectives of empowerment have a magnificent impact on service recovery performance. However, psychological empowerment has a stronger influence on psychological service recovery than tangible service recovery. The results also reveal that the two perspectives of empowerment together have clearly a higher level of impact on service recovery performance than both forms of empowerment does separately. Finally, this research shows that psychological empowerment partially mediates the relationship between structural empowerment and service recovery performance. In this research, new insights into the existing literature, implications and directions for future research are presented.
\end{abstract}

Keywords: employee empowerment, structural / psychological empowerment, service failure, service recovery performance, hotels, and Jordan

\section{Introduction}

In general, the competitiveness of five-star hotels depends on service quality and quality of the delivered services. Ideally, service failure will occur in the service organization, maintaining high level of the quality service is often difficult, no service system is perfect, employees and customers do mistakes in the service organization and the systems itself breakdown. As a result, the planned service process may not achieve the preferred results for customers and the quality of service may not meet the expectations of the customers (Bell and Zemke, 1987). Therefore, service organization is required to provide different service recovery methods to rectify any mistakes that occur in the service organization. However, implementing this is somehow difficult because the inherent variability in tourism and hospitality services is dependent primarily in two factors: the dependency on the service providers and the difficulty of quality inspections prior to consumption (Zeithaml et al., 1988). Further, customers may show their dissatisfaction by providing a compliant and when a complaint is provided, the employees is then responsible for providing effective service recovery methods and handling the situation of service encounter (De Jong and De Ruyter, 2004). If the situation was not handled effectively by the employees who are responsible of the complaint, this may lead to negative consequences such as negative word of mouth and a state of dissatisfaction (Bitner, Booms and Tetreault, 1990). Customer perception of service quality is formed based on how employees provide the service (Masdek et al., 2011) therefore, the role that the employees play in providing service recovery is very vital especially when there is a failure and aggrieved customer in the service encounter. Interestingly, identifying different types of service failure and appropriate methods of service recovery should help in providing opportunity for changing a customer's negative attitude toward the operation to a positive one. 
However, implementing these recovery methods effectively - the service recovery performance - is also critical and depends to a large extent on the empowerment of customer contact employees who are forefront of the service recovery process. Research evidences from a range of authors indicates that empowerment is an effective strategy in supporting the process of service recovery performance, they also indicated to the magnificent role of empowerment on service recovery performance (Karatepe et al., 2014; Kirkbir and Cengiz, 2007; Babakus et al., 2003; Yavas et al., 2003; Enz and Siguaw, 2000; Carson et al., 1998; Hocutt and Stone, 1998; Bowen and Lawler, 1995, 1992; Hart at al., 1990; and Conger and Kanungo 1988).

In general, empowerment is studied very well in the past researches. However, most of the previous researches that are conducted on the relationship between empowerment and service recovery performance were either conducted structural empowerment or psychological empowerment on service recovery performance. Thus, the role of employee empowerment with its two forms together structural empowerment and psychological empowerment that plays on employees' service recovery performance is still undiscovered. How structural empowerment, psychological empowerment and employee empowerment influences service recovery performance remains to some extend uncompleted research area. There is therefore a need to search, from the employees' perspective all the levels of empowerment that are evident in the hotel industry and the influence of empowerment on service recovery performance.

This research was performed in five-star hotels in Jordan. Most of the previous researches on empowerment and service recovery performance have been implemented in the developed countries and with limited evidence in the Middle East and Jordan in particular. However, there is evidence to suggest that implementing this research in other industrial contexts and cultural values can provide different interpretations and directions to empowerment constructs as well as to service recovery performance (Al-Sabi, 2011).

\section{Literature Review}

\subsection{Empowerment}

The literature of management has been presented empowerment in many ways. Each researcher has focused on different aspects of empowerment and consequently has been studied, defined and measured differently. Part of this literature, (Kanter, 1983; Ginnodo, 1997; Eylon and Bamberger, 2000 and Mills and Ungson, 2003), introduces empowerment as structural empowerment. In this perspective, empowerment is considered as management tool centers on the idea of giving the power and control among employees (Kanter, 1983). Others are seen empowerment as policy, practice and structure that give the employees autonomy to take decisions and influence in their work (Eylon and Bamberger, 2000 and Mills and Ungson, 2003). The primary key in this perspective of empowerment is to exchange the power among managers and employees (Al-Sabi, 2011). In this respect, structural empowerment is considered as "employees and managers solve problems and take decisions that were traditionally reserved to higher levels of the organizations" Ginnodo, 1997, p.3).

Although the literature showed that there was no consensus between researchers in conceptualizing structural empowerment, some researchers still considered structural empowerment as one factor (Savery and Luks, 2001; Hartline and Ferrell, 1996; and Chebat and Kollias, 2000), while others seen structural empowerment as multifactors (Bowen and Lawler, 1992; Rafiq and Ahmad, 1998; Randolph and Sashkin, 2002 and Siebert et al, 2004). This difference among researchers is normal, because each researcher is seen empowerment from different corner and dependent on a specific factor or factors. For example, Siebert et al., (2004) considered sharing information is a factor of empowerment, while Melhem (2004) seen sharing information as antecedent of empowerment. The justification of Melhem is that when the managers share the information with employees this should enrich their knowledge and consequently enable them to get better in exercising empowerment. Therefore, Melhem considered sharing information is prior factor to empowerment rather than a factor of empowerment.

The current research is determined training, rewards systems and management style as important factors to empowerment (Al-Sabi, 2011). Thus, this research defines structural empowerment as "the extent to which frontline employees believe that they have been given the autonomy and authority to act independently which may derive from aspects such as training, rewards systems and management style" (Al-Sabi, 2011, p.98). On the other part, the literature has presented empowerment from the psychological perspective. This perspective is viewed as employee's feeling and assessment toward their job and their capability to do their jobs. Psychological empowerment focuses on the internal motivation of the employees rather than on the managerial practices used to enhance levels of power among employees. Therefore, psychological empowerment is conceptualized here as a state of feelings rather than something does to employees. This was supported by Spritzer (1995) who seen psychological empowerment as "a single construct composed in four factors: meaning, competence, self-efficacy, and impact. Together, these four dimensions reflect an individual's active orientation to his or her work role" (P.1444). 
Lee and Koh (2001) provided a comprehensive concept of empowerment and defined it as a psychological sense of employees recognizing four dimensions of meaningfulness, competence, self-determination and impact, which is derived by the empowering behaviors at managerial positions. The point here is that the employees will have their own feelings of psychological empowerment which was created by the attempts of the managerial practices to develop employment environment and help the employees to hold their own work effectively (Amenumey and Lockwood, 2008). In this respect, both forms of empowerment which will form full employee empowerment should serve as a primary key to handle their tasks and take the necessary actions toward them.

Implementing employee empowerment in the service organization is a difficult task (Johnson and Redmond, 1998). Although, managers at the service organization know the difficulty of doing so, they agree to implement employee empowerment. The reason behind this is that they know the organizational goals cannot be achieved with the participation of the entire workforce in the service organization. Therefore, empowerment is considered as a comprehensive strategy to achieve improvements in different areas at the service organization and enable it to compete with other organizations in the market place as well as provide the employees with needed freedom to do their work and take decisions properly (Johnson and Redmond, 1998; and Lashely, 2001).

In the hospitality industry, employee empowerment has also many benefits to employees and organizations. For example, empowered employees are usually having distinguished characteristics that makes them able improve service quality, deal with different types of service failure, provide many multiple methods of service recovery, create anything with job related issues without referring back to senior levels of management and lead the organization to the success in the market place (Lashely, 1995; Kildas, 2001; and Kruja et al., 2016).

\subsection{Service Recovery Performance}

Although best of intentions, trainings, policies and procedures are provided by the service organization, service failure still occur (Cranage and Mattila, 2005). Achieving zero defects in the service organization is somehow difficult and mistakes are an unavoidable challenge for every service encounter (Sparks 2001; Hess, 2008). Thus, service failure is normal to be occurred in the service organizations, especially when there is a high involvement of customer contact employees. Maxham (2001) illustrated that it is not easy for the service organizations to prevent all service failures. However, they can learn how to provide a proper response when failures do occur and develop a recovery strategy in order to respond to service problems. This process is termed service recovery. However, it is important to note that service recovery has been reviewed by other researchers focusing on several conceptual and theoretical bases and using different research methodologies (Lewis and McCann, 2004). Therefore, each researcher has seen service recovery from a particular viewpoint.

Service recovery is seen as efforts by the service organization to correct some customer' perceived service failure (Maxham, 2001). While, Lewis and McCann, (2004) presented service recovery as efforts of employees in solving customer problems and changing the negative attitude of dissatisfied customers and retaining these customers. Others, defined service recovery as a method of turning an aggrieved customer from being dissatisfied to being satisfied after the service has failed to meet customer expectations (Zemke and Bell, 1990). Finally, Tax and Brown (1998) defined service recovery as an oriented approach that is identifying service failure, resolving customer problems, classifying their root causes and yielding data that can be mixed with the other measures so work can be assessed and improved the system of the hospitality organizations. To have a holistic and comprehensive concept of service recovery, this research defines service recovery more broadly as a process owned by the organization and performed by the employees in the service organization with the purpose of determining service failure, correcting customer problems, changing the negative state of the customer from being dissatisfied to satisfied, maintaining these customers and helping to assess and improve the service system. (Al-Sabi, 2011).

Service recovery has a significant role in maintaining customers and keeping them satisfied, making customers more aware about the service organization and, finally, its effectiveness and willingness in solving customer's problem and meeting their expectations. This was encouraged by Zemke (1994) who indicated that when the customers complain and receive a satisfied solution are likely to buy more products than those who have no complain at all with organization nor its services. Therefore, the aim of service recovery is to provide a solution for customer's problems, boost customer's evaluation to the organization and its service quality through meeting their expectations, establish a strong relationship between the organization and the customer through creating high level of their satisfaction and acquire a free advertisement through a positive word of mouth. The literature has clearly shows that effective service recovery can make the customer more satisfied than those who have been serviced correctly in the first time; it can also boost the repeat visit intention of the customer and consequently, acquire more profits for the service organization (Etzel and Silverman, 1981; and Hart et al., 1990). 
Previous researches determined significant means of service recovery methods, these methods can be categorized into two types, namely: psychological service recovery and tangible service recovery (Miller et al., 2000). More specifically, psychological service recovery is seen as efforts by employees to correct service failure through psychological methods (Al-Sabi, 2011; Lewis and McCann, 2004; and Miller et al., 2000). These includes: (acknowledgement, apology, empathy, managerial intervention, customer input, explanation, provide assurance, and own the problem). However, customers in some circumstances expect more efforts besides the psychological methods and if nothing more was provided, customers would seem to be dissatisfied and believe that the efforts were not sincere (Seawright et al., 2008).

Thus, it becomes necessary to present the suggestion of Miller and others, who indicated that tangible methods are more supported and significant in solving most of the incidents of service failure. Tangible service recovery is seen as efforts by employees to complete the primary service, re-perform the service and exchange the product or refund the cost (Lewis and McCann, 2004). Other forms of tangible service recovery methods are presented as follows: (compensation, free gratis, up-grade, refund, discount, coupon, free ancillary, symbol atonement (i.e. value added atonement), correcting, replacement, and urgent reinstatement). (Bell and Zemke, 1987; Bitner et al., 1990; Kelley et al., 1993; Boshoff, 1997; Bowen and Johnston, 1999; Sparks, 2001; Dutta et al., 2007; Johnston and Michel, 2008). It can be noticed from these definitions that different methods of service recovery that it can be used in different incidents of service failure are available for the employees in the service organization.

\subsection{Empowerment and Service Recovery Performance}

Previous researches have indicated that best managerial practice of organizational efforts with regard toservice recovery is to identify them (Ashill et al., 2008; Boshoff and Leong, 1998; Chebat and Kollias, 2000; Lytle and Timmerman, 2006). Empowerment gives the employees a permission to access the available resources in the organization and to meet customer needs as well as provide high-quality service, and this has been evidenced as a flexible element that enhances employees' participation and improves service recovery effectiveness, and results in delivering excellent services (Lashley, 1995; Ashill et al., 2005; Boshoff, 1997; Boshoff and Leong, 1998; Yee et al., 2010; Kim and Oh, 2012; Speier et al., 2011). This research suggests that empowerment centers on the idea that the employees will have their own feelings of psychological empowerment which was created by the efforts of the managerial practices to develop employment environment and help the employees to hold their own work effectively (Amenumey and Lockwood, 2008).

In this respect, it can be argued that there are two ways for empowerment to contribute in the delivery of service recovery. First, structural empowerment allows employees to utilize authority and responsibility as well as to act independently in making decision without going back to superior managers. In addition, it allows employees to get access to the available resources which can be used to enhance the process of service recovery performance (Ashill et al., 2009; Hess et al., 2003; Choi et al., 2014). Second, psychological empowerment will be formed automatically once employees get authority and responsibility as well as to use the available resources to act independently under different circumstances. As such, both structural empowerment and psychological empowerment play as primary keys in enabling employees to solve problems should they arise, as well as to take the necessary and immediate action to deal with the situation in service encounter (Al-Sabi, 2011).

In this way, frontline employees should do their work proactively in conducting solutions for any type of service failure, as they trust their organizations supporting them in the process of conducting service recovery (Zhang and Geng, 2019). When organizations focus on implementing structural empowerment and psychological empowerment effectively, the authority and responsibility to deliver excellent services support employees to emphasis more on solving customer's problems in different service failure incidents (Kim and Oh, 2012). Therefore, empowerment has clearly an important role to implement service recovery and that is through identifying and solving the problem of different incidents in the service encounter (Hart et al., 1990), it is also the way that help employees to correct customer problems and diminish losses from customer problems as well as enhance the efficiency of recovery implementation, thus promoting customer satisfaction (Zhang and Geng, 2019).

Consequently, customers perceived fewer service failures when employees were empowered (Sparks et al., 1997). Randolph (1995); Spreitzer (1996) and Kashyap (2001) indicated that empowered employees mean that they have the flexibility and necessary resources to satisfy customers' needs, and to provide high level of service quality. Bowne and Lawler (1992) found that empowered employees responded to customer needs effectively during the delivery of the service recovery and showed more enthusiasm in their interactions with customers. Carson and colleagues (1998) revealed that employees who perceived a high level of empowerment are tended to be more effective in service failure recovery.

In other words, if employees recognized a limited level of empowerment then, the result will be a mismatch between the organizational arrangement and employees' responses, which will in somehow prevent a rapid solution to be in for service failures (Lytle and Timmerman, 2006; Kim and Oh, 2012; Yee et al., 2010). 
Many prior studies have been investigating the relationship between empowerment and service recovery performance. Part of these studies has confirmed the effective role of empowerment on service recovery performance (Conger and Kanungo, 1988; Hart et al., 1990; Bowen and Lawler, 1992, 1995; Carson, Carson, Eden, and Roe, 1998; Enz and Siguaw, 2000; and Zhang and Geng, 2019).

Other studies conducted in the hospitality industry revealed that empowerment has a significant relationship with service recovery performance. (i.e. Yavas et al., 2010; Crawford and Riscinto-Kozub, 2010; Schumacher and Komppula, 2016).

However, the other studies have also showed the empowerment was ineffective approach in the service recovery performance. For example, Chan and Lam (2011) indicted that when the employees are empowered, they recognized increase in the workload and consequently decrease the performance of the service recovery. This is due to the increased responsibility which creates a great amount of information, and thus employees feel endanger and anxious as a result of empowerment (Zhang and Geng, 2019). Duffy et al. (2006) found that the role of empowered employees was less critical in solving customer's problems in the bank industry than the speedy of corrective action. Hence, it can be said also that it is important to consider in creating high level of satisfaction linked to service recovery efforts is not "who respond and empowered but "how immediate" the response to the service failure (Duffy et al., 2006). That is why Grönroos (1988) indicated that service recovery is a process-related procedure

\section{Research Model}

Figure 1 shows the research's model. The constructs are divided into independent and dependent. The independent constructs include structural empowerment, psychological empowerment and employee empowerment, while the dependent is represented by service recovery performance.

Figure1. Research Model

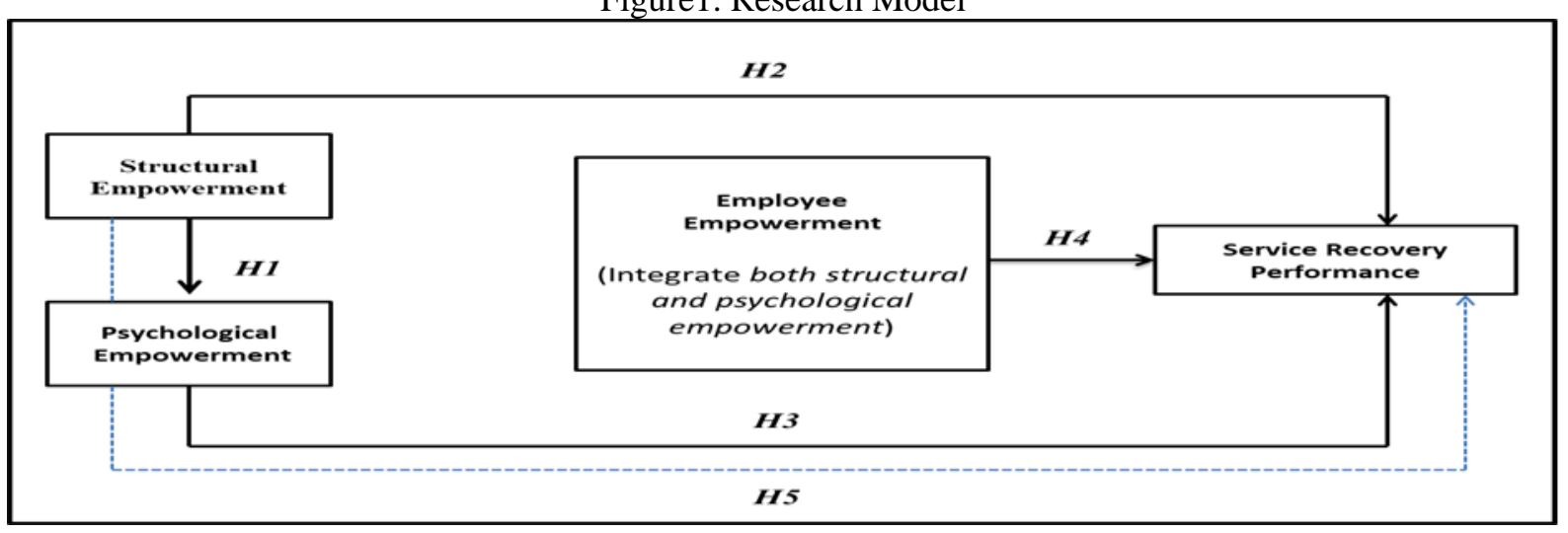

In figure 1, this research is assumed that structural empowerment will have a direct relationship with psychological empowerment and this should result a state of full employee empowerment. Consequently, employee empowerment also is assumed to have a higher level of influence on service recovery performance than structural empowerment and psychological empowerment does individually. The figure also proposes that both forms of empowerment in separate case should have an influence on service recovery performance. Finally, this research also proposed that psychological empowerment mediates the relationship between structural empowerment and service recovery performance.

\subsection{Research Hypotheses}

According to the literature review, this research is proposed the following hypotheses:

Hypothesis 1: Structural empowerment will have a significant impact on psychological empowerment

Hypothesis 2: Structural empowerment will have a significant impact on service recovery performance Hypothesis 3: Psychological empowerment will have a significant impact on service recovery performance Hypothesis 4: Employee empowerment will have a higher level of positivity on service recovery performance than structural empowerment and psychological empowerment does separately.

Hypothesis 5: Psychological empowerment mediates the relationship between structural empowerment and service recovery performance.

\section{Methodology}

\subsection{Research Design and Implementation}


The two main perspectives of empowerment are presented in this research, which both will create on the whole employee empowerment. Therefore, a questionnaire was used to be the best technique with separate sections of the instrument measuring the two variables; empowerment and service recovery performance from the employees' perspective and collecting demographic data. Top five-star hotels in Jordan, keen on the relationship between employee empowerment and service recovery performance, approved to participate in the research and facilitated the distribution of the questionnaires among the employees.

The data were taken from all employees who are working in five-star hotels in Jordan with sample size of 425 employees. A face to face approach was performed to distribute and collect the questionnaires. 298 questionnaires were valid and finally coded into SPSS version 22. The data was analyzed and described through descriptive analysis, exploratory analysis and multiple regression analysis.

Three scales were used to discover the research area between empowerment and service recovery performance. The instrument of this research is divided into four sections. Two sections represent the scale of both forms of empowerment that include structural empowerment and psychological empowerment. Section three presents the scale of service recovery performance. All the scales of this research are adopted scales (Hays, 1994; Spreitzer, 1995; and Boshoff and Allen, 2000; and Al-Sabi, 2011). The last section is contained questions on sample's characteristics (i.e. gender, age, level of education, employment mode and work experience). Back translation procedure was used from the instrument's research.

\subsection{Findings}

\subsubsection{Demographic Characteristics}

To present research's sample a descriptive analysis was used. Table 1 shows the demographic profile of the participants.

Table 1: The Sample's Characteristics

\begin{tabular}{|c|c|c|}
\hline Characteristics & Sample & Percentage \\
\hline \multicolumn{3}{|l|}{ Gender } \\
\hline Male & 235 & $79 \%$ \\
\hline Female & 63 & $21 \%$ \\
\hline \multicolumn{3}{|l|}{ Age } \\
\hline Less than 20 years & 6 & $2 \%$ \\
\hline $20-29$ & 188 & $63 \%$ \\
\hline $30-39$ & 71 & $24 \%$ \\
\hline $40-49$ & 30 & $10 \%$ \\
\hline 50 and more & 3 & $1 \%$ \\
\hline \multicolumn{3}{|l|}{ Level of Education } \\
\hline $\begin{array}{l}\text { Secondary School or } \\
\text { less }\end{array}$ & 54 & $18 \%$ \\
\hline Undergraduate & 229 & $77 \%$ \\
\hline Postgraduate & 15 & $5 \%$ \\
\hline \multicolumn{3}{|l|}{ Employment Mode } \\
\hline Full time & 277 & $93 \%$ \\
\hline Part time & 21 & $7 \%$ \\
\hline \multicolumn{3}{|l|}{ Experience } \\
\hline $1-2$ years & 110 & $37 \%$ \\
\hline $3-4$ years & 80 & $27 \%$ \\
\hline $5-7$ years & 60 & $20 \%$ \\
\hline 8 years and above & 48 & $16 \%$ \\
\hline
\end{tabular}

In Table 1, the findings show that $79 \%$ of participants were male and the rest were female. These numbers reflect the statistics of the hotel worker in Jordan that includes 91\% males and 9\% females (Jordanian Ministry of Tourism and Antiquities, 2020). Concerning age, a $2 \%$ of participants were less than 20 years and the majority of participants were between 20 and 29 years. A $24 \%$ were between 30 and 39 years, $10 \%$ were between 40 and 49 years, and only $1 \%$ was 50 or over. Therefore, the majority of the workforce at Jordanian hotels is young and able to meet hardship work at the Jordanian Hotels. The level of education reported by employees showed that $18 \%$ had secondary school or less, $77 \%$ had undergraduate degree and only $5 \%$ had a postgraduate degree.

These numbers also reflect that most of the workforce in the Jordanian hotels has the knowledge and the basis in working in the hotels industry. For the employment mode, the majority of employees $93 \%$ were a full time and only $7 \%$ a part time. Finally, for the experience character, 37\% percent of the participants were between 1 and 2 years, 27\% between 3 and 4 years, 20\% between 5 and 7 years and the last group 16\% of participants have worked 
8 years and more. All these characteristics to some extent reflect the employees working in five-star hotels in Jordan.

\subsubsection{Validity and Reliability of the Scales}

In a western culture all the scales used in this research are showed validity and reliability results, however, it is necessary to check these scales in a non-western culture and its validity and reliability.

To do so, exploratory factor analysis was performed to show factor loading on the constructs of this research and Cronbach's Alpha to show the construct reliability. Numbers of tables are presented to show the factor analysis after rotation.

Table 2: Factor Analysis for Structural Empowerment

\begin{tabular}{|l|c|c|}
\hline Structural Empowerment & $\begin{array}{c}\text { Item loading } \\
\alpha=84\end{array}$ & Communality \\
\hline SE19, I am encouraged to handle job-related problems & 0.79 & 0.61 \\
\hline $\begin{array}{l}\text { SE16, I am encouraged to use initiative when dealing with job-related } \\
\text { problems }\end{array}$ & 0.78 & 0.61 \\
\hline SE03, I have authority to correct problems when they occur & 0.76 & 0.57 \\
\hline SE17, I have a lot of control over how I do my job & 0.77 & 0.58 \\
\hline $\begin{array}{l}\text { SE18, I do not need management approval before I handle job-related } \\
\text { problems }\end{array}$ & 0.68 & 0.45 \\
\hline $\begin{array}{l}\text { SE26, I am allowed to take charge of problems requiring immediate } \\
\text { attention }\end{array}$ & 0.67 & 0.44 \\
\hline SE01, I am allowed to do almost anything to do a high quality job & 0.65 & 0.42 \\
\hline & & \\
\hline Eigenvalue & 3.7 & \\
\hline Percentage of Variance Explained & $53 \%$ & \\
\hline Cumulative (Total explained) & $53 \%$ & \\
\hline
\end{tabular}

In Table 2, the findings revealed a one-factor solution and confirmed the construct validity of the scale with a 53\% of variance. Item loadings in this construct were 0.65 to 0.79 . The finding of Cronbach Alpha has clearly exceeded the minimum value of $(\alpha=0.70)$, which is the accepted level of exploratory research (Hair et al., 2010).

Table 3: Factor Analysis for Psychological Empowerment

\begin{tabular}{|l|c|c|c|}
\hline Psychological Empowerment & $\begin{array}{c}\text { Item Loading } \\
\text { (Attitude) } \\
\alpha=0.87\end{array}$ & $\begin{array}{c}\text { Item Loading } \\
\text { (Influence) } \\
\alpha=0.76\end{array}$ & Communality \\
\hline MPE02, The work I do is very important to me & 0.83 & & 0.77 \\
\hline CPE04, I am self-assured about my capability to perform my work activities & 0.83 & & 0.72 \\
\hline MPE07, The work I do is meaningful to me & 0.79 & & 0.66 \\
\hline CPE05, I have mastered the skills necessary for my job & 0.74 & & 0.62 \\
\hline MPE09, My job activities are personally meaningful to me & 0.70 & & 0.56 \\
\hline SPE22, I can decide on my own how to go about doing my work & & 0.85 & 0.73 \\
\hline SPE23, I have considerable opportunity for independence in how I do my job & & 0.79 & 0.71 \\
\hline IPE24, My impact on what happens in my department is large & & 0.72 & 0.60 \\
\hline & & & \\
\hline Eigenvalue & 4.2 & 1.2 & \\
\hline Percentage of variance explained & $51.8 \%$ & $15.2 \%$ & \\
\hline Cumulative (Total explained) & & & $67 \%$ \\
\hline
\end{tabular}

Table 3 reveals a two-factor solution and confirmed the construct validity of the scale with a $67 \%$ of variance. Factor 1 is titled in the previous researches 'Attitude' which merges two factors of the original scale: meaning and competence. Item loadings in this factor were 0.70 to 0.83 . Factor 2 is also titled in the previous researches 'Influence' which merges also two factors of this original scale: impact and self-determination. Item loadings in this factor were above 0.70 . The finding of Cronbach Alpha has clearly exceeded the minimum value of $(\alpha=0.70)$ and therefore confirmed the reliability of the scale. 
Table 4: Factor Analysis for Service Recovery Performance

\begin{tabular}{|l|c|c|c|}
\hline Service Recovery Performance & $\begin{array}{c}\text { Item loading } \\
\text { Psychological } \\
\text { service } \\
\text { Recovery } \\
\alpha=82\end{array}$ & $\begin{array}{c}\text { Item loading } \\
\text { Tangible } \\
\text { Service } \\
\text { Recovery } \\
\alpha=83\end{array}$ & Communality \\
\hline $\begin{array}{l}\text { PSR04,I expressed regret for the mistake that the hotel had } \\
\text { made }\end{array}$ & 0.76 & 0.73 & 0.59 \\
\hline PSR03,I admitted responsibility for the mistake & 0.72 & 0.53 \\
\hline $\begin{array}{l}\text { PSR01,I apologized for the inconvenience that the problem had } \\
\text { brought to the customer }\end{array}$ & 0.71 & 0.52 \\
\hline $\begin{array}{l}\text { PSR08,I asked my managers to contribute to solving the } \\
\text { customer problem }\end{array}$ & 0.66 & 0.54 \\
\hline $\begin{array}{l}\text { PSR17,Considering all the things I do, I handled this dissatisfied } \\
\text { customers quite well }\end{array}$ & 0.62 & 0.47 \\
\hline $\begin{array}{l}\text { PSR16,I provided assurance that the problem would not occur } \\
\text { again }\end{array}$ & 0.57 & & 0.45 \\
\hline PSR09,I told the customer what I had done to solve the problem & 0.54 & & 0.40 \\
\hline PSR11,I ensured by myself that the problem has been solved & 0.53 & & 0.38 \\
\hline $\begin{array}{l}\text { PSR20,I told the customer what I was going to do the rectify the } \\
\text { problem }\end{array}$ & & 0.80 & 0.36 \\
\hline $\begin{array}{l}\text { TSR04,I gave compensation for the current stay in the hotel } \\
\text { (e.g. discount, upgrade, Fund, etc) }\end{array}$ & & 0.80 & 0.70 \\
\hline TSR05,I offered a discount for a higher room category & & 0.70 & 0.55 \\
\hline TSR03,I offered an upgradeto a higher room category & & 0.63 & 0.50 \\
\hline TSR02,I gave compensation for a future stay in the hotel & & 1.8 & \\
\hline TSR01,I offered complimentary coffee or tea & $37 \%$ & $13 \%$ & \\
\hline & & & $50 \%$ \\
\hline Eigen-value & & & \\
\hline Percentage of variance explained & & & \\
\hline Cumulative (Total explained) & & & \\
\hline
\end{tabular}

As shown above in Table 4, the findings show a two-factor solution and confirmed the construct validity of the scale with a $50 \%$ of variance. Factor 1 is titled 'Tangible service recovery'. Item loading in this factor were 0.53 to 0.76. Factor 2 is also titled 'psychological service recovery'. Item loadings in this factor were above 0.60 . The finding of Cronbach Alpha has clearly exceeded the minimum value of 0.70 and this confirmed the reliability of the scale.

\subsubsection{Descriptive Statistics of the Research's Variables}

After checking the validity and the reliability of the scales, a descriptive analysis is presented for the overall constructs and its sub-dimensions.

Table 5: The Descriptive Analysis (No = 298)

\begin{tabular}{|c|c|c|c|c|}
\hline Scales & Extracted Factors & Mid-scale & Mean & Std. Deviation \\
\hline $\begin{array}{c}\text { Employee } \\
\text { Empowerment }\end{array}$ & Overall & 4 & 5.91 & 1.044 \\
\hline $\begin{array}{c}\text { Structural } \\
\text { Empowerment }\end{array}$ & Overall & 4 & 5.59 & 1.001 \\
\hline $\begin{array}{l}\text { Psychological } \\
\text { Empowerment }\end{array}$ & Overall & 4 & 5.92 & .858 \\
\hline \multirow{2}{*}{$\begin{array}{l}\text { Psychological } \\
\text { Empowerment }\end{array}$} & Attitude (1) & 4 & 6.06 & .919 \\
\hline & Influence (2) & 4 & 5.69 & 1.083 \\
\hline $\begin{array}{c}\text { Service } \\
\text { Recovery } \\
\text { Performance }\end{array}$ & Overall & 4 & 5.73 & .825 \\
\hline \multirow{2}{*}{$\begin{array}{c}\text { Service } \\
\text { Recovery } \\
\text { Performance }\end{array}$} & $\begin{array}{c}\text { Psychological } \\
\text { Service Recovery }\end{array}$ & 4 & 5.99 & .800 \\
\hline & $\begin{array}{l}\text { Tangible Service } \\
\text { recovery }\end{array}$ & 4 & 5.26 & 1.257 \\
\hline
\end{tabular}


All the scales in this research were computed by the means' scores of its sub-scales. The result in table 5 shows that all the scales has clearly exceeded the mid-point scale 4 and ranged from 5.26 to 6.06. Concerning employee empowerment, the mean score for an overall scale is 5.91 with a standard deviation (S.D) at 1.044. This reflects the ability that the employer has to empower his/her employees would affect the employees' assessment of the four dimensions of psychological empowerment was performed effectively and consequently the employees in the Jordanian hotels were highly believed that they were empowered structurally and psychologically.

More specifically, the mean score of structural empowerment as one-factor is 5.59 with standard deviation (S.D) at 1.001. This means, the employees believe that they were give the autonomy and the authority to act independently and illustrates also they were highly structurally empowered.

Regarding psychological empowerment, the mean score for an overall is 5.92 with a standard deviation (S.D) at 0.858 . This means that the employees believed in all the cognition of psychological empowerment effectively. On one hand, meaning and competence (attitude) with a mean score is 6.06 and on the other hand, self-determination and impact (influence) with a mean score is 5.69. Inevitably, the employees were highly psychologically empowered.

Regarding service recovery performance, the mean score for an overall is 5.73 with a standard deviation (S.D) at 0.825. This means that the Jordanian workforce at five-star hotels perceived all the factors of service recovery performance and performed the process of identifying service failures, resolving customer problems, changing the negative attitude of dissatisfied customers to a state of satisfaction and retaining these customers, while helping to assess and improve the service system effectively. On one hand, (tangible service recovery) with a mean score is 5.26 and on the other hand, (psychological service recovery) with a mean score is 5.99. Inevitably, the employees were perceived service recovery performance highly.

\subsubsection{Correlation Analysis}

Correlation analysis at this stage of the research provides an initial indicator of the relationships among the variables. Therefore, all the variables without the sub-scales were subjected to this analysis with an exception for service recovery performance variable and presented in Table 6 .

Table 6: The Correlation between Variables

\begin{tabular}{|l|l|l|l|l|l|l|}
\hline \multicolumn{2}{|c}{} & SE* & PE* & SRP & TSR & PSR \\
\hline \multirow{3}{*}{$\begin{array}{l}\text { Structural } \\
\text { Empowerment }\end{array}$} & Pearson Correlation & 1 & $.711^{* *}$ & $.554^{* *}$ & $.473^{* *}$ & $.471^{* *}$ \\
\cline { 2 - 8 } & Sig. (2-tailed) & .000 & .000 & .000 & .000 & .000 \\
\cline { 2 - 8 } & $\mathrm{N}$ & 298 & 298 & 298 & 298 & 298 \\
\hline \multirow{3}{*}{$\begin{array}{l}\text { Psychological } \\
\text { Empowerment }\end{array}$} & Pearson & $.711^{*}$ & 1 & $.534^{*}$ & $.332^{*}$ & $.562^{*}$ \\
& Correlation & $*$ & 1 & $*$ & $*$ & $*$ \\
\cline { 2 - 8 } & Sig. (2-tailed) & .000 & .000 & .000 & .000 & .000 \\
\cline { 2 - 8 } & $\mathrm{N}$ & 298 & 298 & 298 & 298 & 298 \\
\hline \multirow{3}{*}{$\begin{array}{l}\text { Full } \\
\text { Empowerment }\end{array}$} & Pearson & $.802^{*}$ & $.853^{*}$ & $.566^{*}$ & $.406^{*}$ & $.559^{*}$ \\
& Correlation & $*$ & $*$ & $*$ & $*$ & $*$ \\
\cline { 2 - 8 } & Sig. (2-tailed) & .000 & .000 & .000 & .000 & .000 \\
\cline { 2 - 8 } & $\mathrm{N}$ & 298 & 298 & 298 & 298 & 298 \\
\hline
\end{tabular}

$* \mathrm{SE}=$ Structural Empowerment $* \mathrm{PE}=$ Psychological Empowerment $* \mathrm{SRP}=$ Service Recovery Performance *TSR= Tangible Service Recovery *PSR= Psychological Service Recovery

The results in table 6 shows a high correlation between 'structural empowerment' and 'service recovery performance' $(\mathrm{r}=0.544)$. The 'psychological empowerment' variable shows also a high correlation with 'service recovery performance' $(\mathrm{r}=0.534)$. Interestingly, 'employee empowerment' variable shows a higher level of correlation with service recovery performance variable than both forms of empowerment does separately $(\mathrm{r}=$ 0.566). On the other side, the correlations between empowerment and service recovery dimensions were also significant. More specifically, it can be seen from the table 6 that an overall 'employee empowerment' is highly correlated with the two dimensions of 'service recovery performance, (i.e. $r=0.406$ for 'tangible service recovery' and $r=0.559$ for 'psychological service recovery'). Finally, an overall 'structuralempowerment' and an overall 'psychological empowerment' reveal also a medium and high correlation with the two dimensions of service recovery performance $(r=0.473, r=0.332)$ for tangible service recovery and $(r=0.571, r=0.562)$ for psychological service recovery performance respectively. Initially, these findings confirm that empowerment is implemented effectively in the Jordanian hotels and the employees are conducted the process of identifying service failures, resolving customer problems, changing the negative attitude of dissatisfied customers to a state of satisfaction and retaining these customers, while helping to assess and improve the service system effectively. 
Furthermore, the findings also confirm that psychological empowerment is more significant with psychological service recovery than tangible service recovery.

\subsubsection{Testing Hypotheses}

To check the hypotheses of this research, a multiple regression technique is performed. Multiple regression analysis is a technique that can be used measure the relationship between a single dependent variable and several independent variables (Hair, et al., 2010).

This technique also provides an idea about how well the independent variable will contribute in the dependent variable and show the overall prediction. In this research, all the variables are metric and therefore divided into independent, and dependent. Structural empowerment, psychological empowerment and full empowerment worked as the independent variables, and service recovery performance worked as the dependent variable. Testing hypotheses is presented as follows:

\section{H1: Structural empowerment will have a positive and significant impact on psychological empowerment.}

This research has assumed that structural empowerment will have a significant impact on employees' psychological empowerment. Table 7 presents the statistical results between structural empowerment and psychological empowerment.

Table 7: The Result between Structural Empowerment and Psychological Empowerment

\begin{tabular}{|c|c|c|c|c|c|}
\hline \multirow{2}{*}{ Independent } & \multicolumn{5}{|c|}{ Dependent } \\
\cline { 2 - 6 } $\begin{array}{c}\text { Structural } \\
\text { Empowerment }\end{array}$ & $\boldsymbol{\beta}$ & $\mathbf{t}$ & $\mathbf{P}$ & $\mathbf{P}$ & $\mathbf{F}$ \\
\cline { 2 - 6 } & 0.71 & 17.50 & 0.000 & 0.51 & 306.36 \\
\hline
\end{tabular}

The result in table 7 shows that structural empowerment is a significant predictor of psychological empowerment. Statistically, it can be seen that the value between structural empowerment and psychological empowerment is $(\beta=$ 0.71 and $\mathrm{P}$ value $<0.01$ ).

Finally, the overall model statistic in Table $7,(\mathrm{R} 2=0.51, \mathrm{p}=0.000)$, supported the view that structural empowerment has a significant influence on psychological empowerment, and therefore empowering the employees structurally through given them the autonomy and the authority to act independently leads them to feel psychologically empowered. Hence, the hypothesis (H1) is accepted.

\section{H2: Structural empowerment will have a positive and significant impact on service recovery performance.}

Structural empowerment is proposed to have a positive and significant impact on service recovery performance. Table 8 presents the statistical results between structural empowerment and service recovery performance.

Table 8: The Result between Structural Empowerment and Service Recovery Performance

\begin{tabular}{|c|c|c|c|c|c|}
\hline \multirow{2}{*}{ Independent } & \multicolumn{5}{|c|}{ Dependent } \\
\cline { 2 - 6 } $\begin{array}{c}\text { Structural } \\
\text { Empowerment }\end{array}$ & $\boldsymbol{\beta}$ & $\mathbf{T}$ & $\mathbf{\text { Value }}$ & $\mathbf{R}^{\mathbf{2}}$ & $\begin{array}{c}\mathbf{F} \\
\text { Ratio }\end{array}$ \\
\cline { 2 - 6 } & 0.55 & 11.30 & 0.000 & 0.30 & 127.70 \\
\hline
\end{tabular}

The result in table 8 shows that structural empowerment is a significant predictor of service recovery performance. Statistically, it can be noted that the value between structural empowerment and service recovery performance is $(\beta$ $=0.55$ and $\mathrm{P}$ value $<0.01$ ). More clearly will be presented in table 9 which shows the results of the relationship between structural empowerment and the dimensions of service recovery performance.

Table 9: The Result between Structural Empowerment and Service Recovery Performance Dimensions

\begin{tabular}{|c|c|c|c|c|c|c|c|c|c|c|}
\hline \multirow{2}{*}{ Independent } & \multicolumn{10}{|c|}{ Dependent } \\
\hline & \multicolumn{5}{|c|}{ Tangible Service Recovery } & \multicolumn{5}{|c|}{ Psychological Service Recovery } \\
\hline \multirow[t]{2}{*}{$\begin{array}{c}\text { Structural } \\
\text { Empowerment }\end{array}$} & $\boldsymbol{\beta}$ & $\mathbf{t}$ & $\underset{\text { Value }}{\mathbf{P}}$ & $\mathbf{R}^{2}$ & $\begin{array}{c}\mathbf{F} \\
\text { Ratio }\end{array}$ & $\boldsymbol{\beta}$ & $\mathbf{t}$ & $\underset{\text { Value }}{\mathbf{P}}$ & $\mathbf{R}^{2}$ & $\begin{array}{c}F \\
\text { Ratio }\end{array}$ \\
\hline & 0.47 & 9.11 & 0.000 & 0.22 & 83.05 & 0.47 & 9.23 & 0.000 & 0.22 & 85.31 \\
\hline
\end{tabular}

In table 9, the results show that structural empowerment is highly significant with both tangible and psychological service recovery. This illustrates that structural empowerment is a significant predictor for the both dimensions of employees' service recovery performance. Statistically, it can be noticed from the table above that the value 
between structural empowerment and the both dimensions of service recovery was almost same $(B=0.47, \mathrm{P}<0.01)$. Finally, in table 8 the overall model statistic $(\mathrm{R} 2=0.30, \mathrm{P}=0.000)$ affirms that structural empowerment positively influenced on employees' service recovery performance. Thus, hypothesis (H2) is accepted.

\section{H3: Psychological empowerment will have a positive and significant impact on service recovery performance.}

Psychological empowerment is suggested to have a significant impact on service recovery performance. Table 10 shows the statistical results between psychological empowerment and service recovery performance.

Table 10: The Result between Psychological Empowerment and Service Recovery Performance

\begin{tabular}{|l|l|l|l|l|l|}
\hline \multirow{2}{*}{ Independent } & \multicolumn{4}{|l|}{ Dependent } \\
\cline { 2 - 6 } & \multicolumn{4}{|l|}{ Service Recovery Performance } \\
\hline $\begin{array}{l}\text { Psychological } \\
\text { Empowerment }\end{array}$ & $\boldsymbol{\beta}$ & $\mathbf{t}$ & $\mathbf{\mathbf { P }}$ & $\mathbf{R}^{\mathbf{2}}$ & $\mathbf{F}$ \\
\cline { 2 - 6 } & 0.53 & 10.76 & .000 & 0.28 & 115.92 \\
\hline
\end{tabular}

The result in table 10 reflects that psychological empowerment is a significant predictor of service recovery performance. Statistically, it can be showed that the value between psychological empowerment and service recovery performance is $(\beta=0.53$ and $\mathrm{P}$ value $<0.01)$. Moreover, the results in table 11 present the result between psychological empowerment and service recovery dimensions.

Table 11: The Result between Psychological Empowerment and Service Recovery Performance Dimensions

\begin{tabular}{|c|c|c|c|c|c|c|c|c|c|c|}
\hline \multirow{2}{*}{ Independent } & \multicolumn{10}{|c|}{ Dependent } \\
\hline & \multicolumn{5}{|c|}{ Tangible Service Recovery } & \multicolumn{5}{|c|}{ Psychological Service Recovery } \\
\hline \multirow[t]{2}{*}{$\begin{array}{l}\text { Psychological } \\
\text { Empowerment }\end{array}$} & $\boldsymbol{\beta}$ & $\mathbf{T}$ & $\frac{\mathbf{P}}{\text { Value }}$ & $\mathbf{R}^{2}$ & $\begin{array}{l}\text { F } \\
\text { Ratio }\end{array}$ & $\boldsymbol{\beta}$ & $\mathbf{t}$ & $\frac{P}{\text { Value }}$ & $\mathbf{R}^{2}$ & $\begin{array}{l}\text { F } \\
\text { Ratio }\end{array}$ \\
\hline & 0.33 & 6.15 & .000 & 0.11 & 37.91 & 0.56 & 11.56 & .000 & 0.31 & 133.65 \\
\hline
\end{tabular}

From table 11, the results show that psychological empowerment is more significant predictor with psychological service performance than tangible service recovery performance.

Statistically, it can be revealed that the result between psychological empowerment and psychological service recovery $(\mathrm{p}=0.56, \mathrm{P}<0.01)$ is the highest. With referring to table 10 , the result of $(\mathrm{R} 2=0.28, \mathrm{P}=0.000)$ confirms that psychological empowerment positively influenced on employees' service recovery performance. Thus, hypothesis (H3) is accepted.

H4: Employee empowerment will have a higher level of positivity on service recovery performance than structural and psychological empowerment does when both taken separately.

Employee empowerment is proposed to have a higher level of positivity on service recovery performance than structural and psychological empowerment does when both taken separately. Table 12 shows the statistical results between employee empowerment and service recovery performance.

Table 12: The Result between Employee Empowerment and Service Recovery Performance

\begin{tabular}{|c|c|c|c|c|c|}
\hline \multirow{2}{*}{ Independent } & \multicolumn{5}{|c|}{ Dependent } \\
\cline { 2 - 6 } & \multicolumn{5}{|c|}{ Service Recovery Performance } \\
\hline $\begin{array}{c}\text { Employee } \\
\text { Empowerment }\end{array}$ & $\boldsymbol{\beta}$ & $\mathbf{t}$ & $\mathbf{\underline { \mathbf { P } }}$ & $\mathbf{R}^{\mathbf{2}}$ & $\mathbf{F}$ Ratio \\
\cline { 2 - 6 } & 0.56 & 11.821 & 0.000 & 0.32 & 139.729 \\
\hline
\end{tabular}

The result in Table 12 reveals that employee empowerment is a more significant predictor on service recovery performance than structural empowerment and psychological empowerment does. Statistically, it can be seen that the value between employee empowerment and service recovery performance $(\beta=0.56$ and $\mathrm{P}$ value $<0.01)$ which is the highest among the relationships of empowerment and service recovery performance. In table 13, the results presented below reflect the result between employee empowerment and the dimensions of service recovery performance. 
Table 13: The Result between Employee Empowerment Service Recovery Performance Dimensions

\begin{tabular}{|c|c|c|c|c|c|c|c|c|c|c|}
\hline \multirow{3}{*}{$\begin{array}{c}\text { Independent } \\
\text { Employee } \\
\text { Empowerment }\end{array}$} & \multicolumn{10}{|c|}{ Dependent } \\
\hline & \multicolumn{5}{|c|}{ Tangible Service Recovery } & \multicolumn{5}{|c|}{ Psychological Service Recovery } \\
\hline & $\boldsymbol{\beta}$ & $\mathbf{T}$ & $\underset{\text { Value }}{\stackrel{p}{l}}$ & $\mathbf{R 2}$ & $\begin{array}{c}\mathbf{F} \\
\text { Ratio }\end{array}$ & $\boldsymbol{\beta}$ & $\mathbf{t}$ & $\underset{\text { Value }}{\stackrel{p}{l}}$ & $\mathbf{R 2}$ & F Ratio \\
\hline & 0.40 & 7.640 & 0.000 & 0.16 & 58.376 & 0.55 & 11.608 & 0.000 & 0.31 & 134.739 \\
\hline
\end{tabular}

The result in Table 13 shows that employee empowerment is more significant predictor with psychological service performance than tangible service recovery performance. Statistically, it can be revealed that the value between employee empowerment and psychological service recovery $(\mathrm{p}=0.55, \mathrm{P}<0.01)$ is the highest.

With referring to table 12 , the statistic result $(\mathrm{R} 2=0.32, \mathrm{P}=0.000)$ confirms that employee empowerment, as a result of integrating both structural empowerment and psychological empowerment, is having a higher level of positivity on service recovery performance than structural and psychological empowerment does separately. Thus, hypothesis (H4) is accepted.

H5: Psychological empowerment mediates the relationship between structural empowerment and service recovery performance.

To examine the mediating hypotheses, this research has adopted Baron and Kenny's (1986) model in verifying the required conditions of mediation. Figure 2 shows the mediating rules of the mediating variable.

Figure 2: The Mediating Rules of the Mediating Variable.

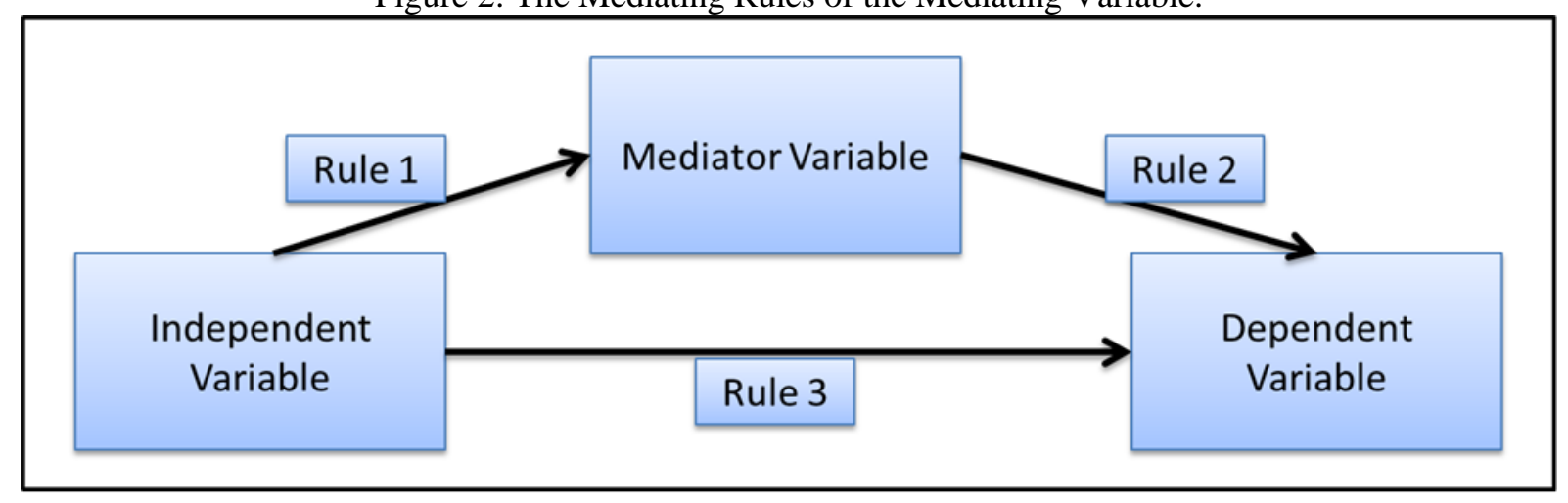

In figure 2, three rules should be met to consider the mediating variable. In the first rule, the independent variable must be correlated with the mediator variable, the independent variable must be correlated with the dependent variable in the second rule, and the mediator variable must be correlated with the dependent variable in the third rule. If all these rules have been met, the next step is to put the independent, the mediator and the dependent variables in one regression equation. A full mediation appears only when the relationship between the independent and the dependent variable disappeared but if the relationship between the independent and the dependent is reduced, this means that the relationship is partially mediated by the mediator variable when is added to the model.

Psychological empowerment is assumed to mediate the relationship between structural empowerment and service recovery performance. Table 14 shows the results of the relationship between structural empowerment and service recovery performance mediated by psychological empowerment.

Table 14: Regression Model Statistics Independent, Mediators and Dependent

\begin{tabular}{|c|c|c|c|c|c|}
\hline \multirow{3}{*}{ Independent } & \multicolumn{5}{|c|}{ Dependent } \\
\hline & \multicolumn{5}{|c|}{ Service Recovery Performance } \\
\hline & $\boldsymbol{\beta}$ & $\mathbf{t}$ & $\frac{\mathbf{P}}{\text { Value }}$ & $\mathbf{R 2}$ & $\begin{array}{c}\mathbf{F} \\
\text { Ratio }\end{array}$ \\
\hline $\begin{array}{c}\text { Structural } \\
\text { Empowerment }\end{array}$ & 0.34 & 5.212 & 0.000 & \multirow{2}{*}{0.37} & \multirow{2}{*}{89.092} \\
\hline $\begin{array}{l}\text { Psychological } \\
\text { Empowerment }\end{array}$ & 0.32 & 4.933 & 0.000 & & \\
\hline
\end{tabular}

In table 14, the results show that the rules of the mediating variable as stated in Baron and Kenny's model have been met. The relationship between structural empowerment and service recovery performance is partially mediated by psychological empowerment. 
This is because the significant relationship between structural empowerment and service recovery performance is reduced from $\beta=0.55$, $\mathrm{P}$ value $=0.000$, to $\beta=0.34$, $\mathrm{P}$ value $=0.000$ when the mediator variable (psychological empowerment) is included in the model. Hence, hypothesis (H5) is accepted

Figure 3: Summary of the Result's Research

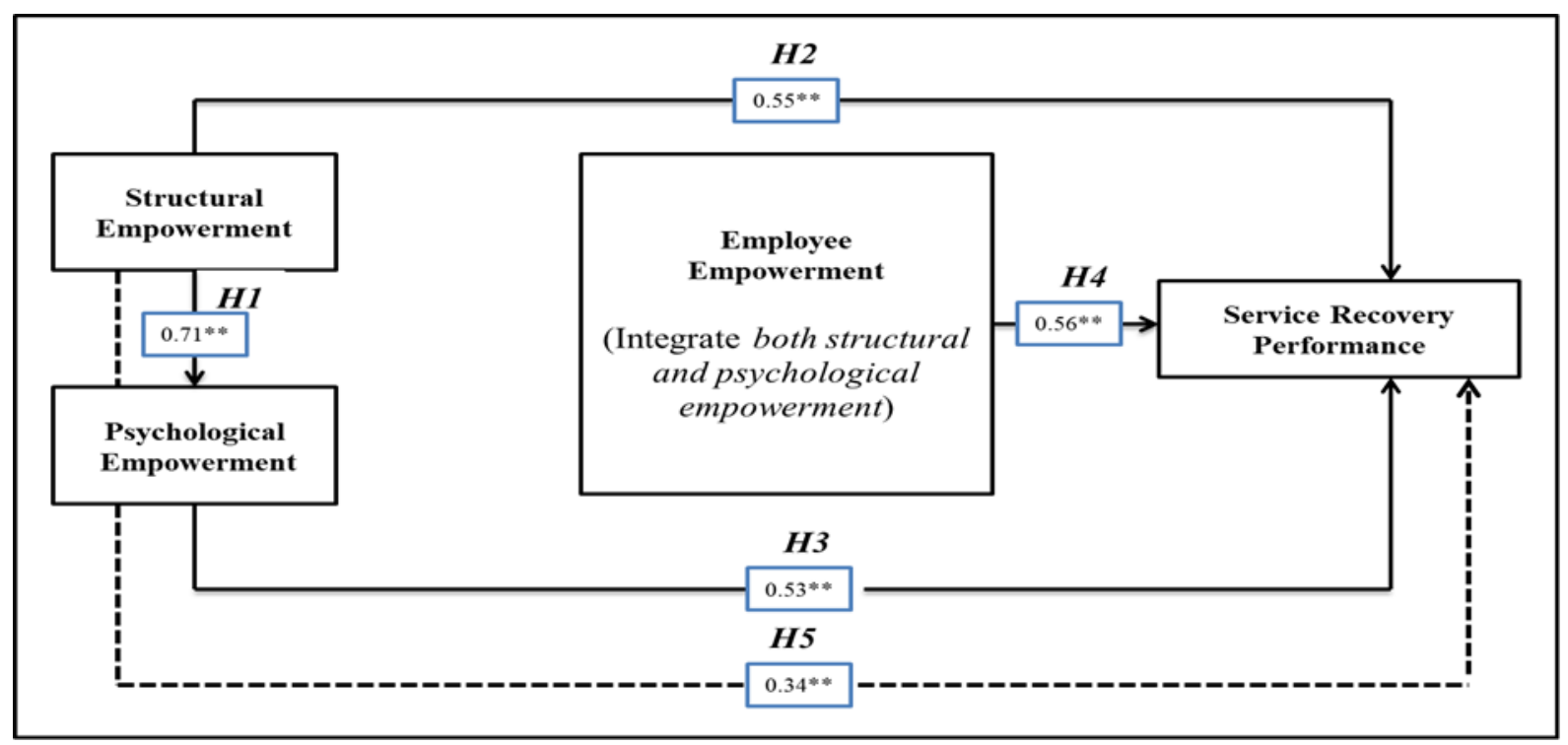

\section{Discussion}

Based on the literature, this research has developed a questionnaire for measuring the constructs of this researchat five-star hotels in Jordan. Exploratory factor analysis and multiple regression are performed. This was for validating and testing different relationships were proposed in this research. The results show that the structure of the extracted factors is the only difference between this research and other researches. More clearly, structural empowerment as one-factor solution is consistent with many studies that considered structural empowerment as a one-factor construct (Hartline and Ferrel, 1996; Chebat and Kollias, 2000; Savery and Luks, 2001; and Al-Sabi, 2011). Structural empowerment as one-factor solution revealed an Alpha Coefficient of 0.84, which exceed the minimum level of 0.70 .

Psychological empowerment as two-factor solution shows contrary to expectations and different from Sprietzer's scale. In the current research, psychological empowerment scale with two-factor solution is consistent with previous studies such as (Kim and George, 2005 and Al-Sabi, 2011). The two-factor solution showed an Alpha Cofficient of 0.87 for attitude and 0.76 for influence, which also exceed the minimum level of 0.70 .

Regarding service recovery performance as two-factor solution is consistent with previous researches but with different presentation for the items structure (Miller et al., 2000 and Al-Sabi, 2011).

The two-factor solution reveal that service recovery performance with its two dimensions had an alpha of 0.82 for psychological service recovery and 0.83 for tangible service recovery, which both exceeded the minimum level of 70. Therefore, the current research affirms that all the constructs of this research are reliable and valid at the fivestar hotels in Jordan.

The aim of this research is to examine different relationships between empowerment and service recovery performance at the level of five-star hotels in Jordan. The findings introduce a support the magnificent impact between structural empowerment and psychological empowerment. This illustrates that the managerial practices conveyed properly to employees and reflects that employees perceived structural empowerment and psychological empowerment effectively. This result is consistent previous research which approved the relationship between structural empowerment and psychological empowerment (Sood, 2007; Amenumey and Lockwood, 2008; and AlSabi, 2011).

The findings also present another support between structural empowerment and service recovery performance. This explains that having an employment environment in the service organization where the employees get the needed authority and responsibility will boost them to act independently and conduct the process of service recovery performance effectively. Consequently, identifying service failures, resolving customer problems, changing the negative attitude of dissatisfied customers to a state of satisfaction and retaining these customers, assessing and improving the service system should be done effectively. The contribution of structural empowerment on both tangible service recovery and psychological service recovery was significant. This also explains the importance of structural empowerment for the dimensions of service recovery performance in the Jordanian hotels. 
These findings are consistent with previous researches that confirmed the magnificent role of structural empowerment on service recovery performance dimensions. Therefore, these findings are attributed to be additional contributions to the literature of empowerment and service recovery (Hart et al., 1990; Bowen and Lawler, 1992, 1995; Magnini and Ford, 2004; Bamford and Xystouri, 2005 and Al-Sabi, 2011).

Further, the findings provide a confirmation of the relationship between psychological empowerment and service recovery performance. This means that the employees have confidence on all the cognitions of psychological empowerment and this in turn will drive the employees to deal with the process of service recovery performance as required at different situation in the Jordanian hotels. Interestingly, the findings reveal that psychological empowerment has more effect on psychological service recovery than tangible service recovery. This also explains that when the employees are psychologically empowered they will be able more to provide psychological methods of service recovery (i.e. acknowledgement, apology, empathy, managerial intervention, customer input, explanation, provide assurance, and own the problem etc). These findings also were confirmed by previous researches such as (Carson et al., 1998; Lee and Koh, 2001 and Al-Sabi, 2011).

The findings of this research support the argument that said when both forms of empowerment merged together as one construct (employee empowerment) the influence on service recovery will be higher than structural empowerment or psychological empowerment does alone. This explains the importance of conducting empowerment in sequence, starting with structural empowerment and ended with the feeling of being empowered. By doing so, the employees at five-star hotels in Jordan will be more free in dealing with the situations that required appropriate methods of service recovery. This finding is approved by Uzunbacak (2015) who declared that the employees are very much appreciated the effort of empowerment, their participation in management and the given authority to make proper decision in different positions in service recovery performance.

Finally, the findings present a new contribution to the knowledge of empowerment and service recovery performance, which is psychological empowerment partially mediate the effect between structural empowerment and service recovery performance. These results convey the importance role of the employees in being psychological empowered on both constructs. Some of the previous studies have measured the mediation role of those who are psychologically empowered with many constructs such as organizational commitment, work redesign, total quality management and innovation performance (Knol and Van Linge, 2009; and Chen and Chen, 2008). Thus, to the best of our knowledge, this research is one of the first researches that has confirmed this relationship.

\subsection{Theoretical and Managerial Implications}

Based on the results which are taken from a five-star hotels in Jordan, theoretical contribution and several important implications are added to the knowledge of empowerment and service recovery performance. The findings in this research showed that the constructs with its structure are valid and reliable between the employees who are working at five-star hotels in Jordan. Thus, the research's questionnaire is approved to be a useful instrument and can be used in other researches with different contexts.

Side of the findings confirmed that structural empowerment has a positive influence on service recovery and provided an equal influence on employees' tangible service recovery and psychological service recovery. On the other side of the findings also approved that psychological empowerment has a positive influence on employees' service recovery and confirmed its magnificent role on psychological service recovery rather than tangible service recovery. Moreover, the literature of hospitality showed that most of researches were tended to use either structural empowerment or psychological empowerment and none has thought of adopting both forms of empowerment together on measuring its influence on service recovery performance in developing countries.

Therefore, the findings confirmed that integrating both forms of empowerment is confirmed to be more effective on service recovery performance than both forms of empowerment do separately. In addition, the findings showed the significant role of psychological empowerment as a mediator between structural empowerment and service recovery performance. In addition, these findings and contribution add more strength to the translated scales, which can be utilized in the future in the developing countries.

In the current research, several managerial implications can be presented. The managers who are working in the level of five-star hotels should understand the primary role of structural empowerment on service recovery performance. This can be achieved by conducting training program, benefiting of rewarding systems and changing management styles which may lead the employees to practice their work independently in the process of service recovery performance. All managers at all levels in the Jordanian hotels should be aware of the complementary effect of structural empowerment on psychological empowerment and consequently on service recovery performance. 
More specifically, when the managers provide the employees with the required the authority and responsibility to do their job without referring back to them, this will increase the psychological side of empowerment and inevitably will increase the level of implementing different methods of service performance effectively.

It is important for the managers in five-star hotels in Jordan to be aware of employee empowerment construct, which resultant from integrating both forms of empowerment together, that has a very distinguished role on implementing service recovery performance. This is due to the multiple effect of empowerment on service recovery performance as it has been shown in the results of this research.

One more useful bit for the managers is to take in their considerations the psychological sense of empowerment and its effect on psychological service recovery. More clearly, the psychological sense of empowerment increases the ability of the employees to provide multiple methods of psychological service recovery methods than tangible service recovery. The benefit of doing so appears to be less costly to the hotel departments in rectifying the problem, retaining the customers and changing the negative attitude of customers from being dissatisfied to satisfy.

The findings in this research showed that psychological empowerment has provided a partial support between structural empowerment and service recovery performance and not full. This gives the managers an indicator to work more on the implementation of structural empowerment which should through this increase the sense of psychological side of empowerment among the employees and consequently on employees' service recovery performance. Finally, it is useful for the managers to get benefit of the designed questionnaire and use it from time to time to get feedback of where are they standing in terms of empowerment and service recovery performance.

\subsection{Limitation and Direction for Future Research}

To understand the research's findings, some limitations and recommendations for future research have been identified and required some attention. This research was conducted only at five-star hotels in Jordan and this advises future researchers to test the model of this research in other service sectors and to improve the generalization of the research's findings. Testing the research's model from managerial and customer perspectives is advised for other researches, this may enrich the literature of empowerment and service recovery performance. The Arabic translated version of the measurement variables in this research should to be tested again in different working environments other than Jordan. Examinations of these variables in other working environments that have similar characteristics to the context of this research, (such as Saudi Arabia, Kuwait, and the United Arab Emirates, etc.), are important to the research's findings and could confirm whether empowerment is a universal approach or not. Therefore, comparing the findings of this research from the employees' perspective with similar contexts in the Middle East is highly recommended, as that may also generalize the validity of the research's findings.

Finally, the sample size of the current research has violated one of the assumptions required to run Structural Equation Modelling (SEM) analysis and it was not possible to conduct a SEM, therefore multiple regressions were used instead to measure the relationships between the constructs of this research Hence, it is suggested to use SEM that serves to test directly and indirectly the effect of all the variables in the research model together, providing robust measure and complete picture to the fit of the entire model and possibly a new results, interpretations and explanations may arise regarding empowerment and service recovery performance.

\section{Conclusion}

This research aimed to examine different relationships between empowerment and service recovery performance at five-star hotels in Jordan. The findings as presented in Figure 3, supported the hypotheses, bridged the gaps and the empirical findings between empowerment and service recovery performance.

More specifically, the findings revealed that both forms of empowerment are significant with service recovery performance, however, psychological empowerment showed more influence on psychological service recovery than tangible service recovery. The findings also showed that merging both forms of empowerment together in one construct revealed higher level of significance than both forms does separately. Finally, this research also showed that psychological empowerment partially mediates the relationship between structural empowerment and service recovery performance.

Although this research has some limitations such as the findings are not representative, they do however provide new insights and directions for other researchers in the future in this research area. The researchers of this research hope from researchers and practitioners to use the contributions, build upon it, and intervenes other constructs related to this research area of the hospitality industry such as job satisfaction, managerial support, training and experience as mediating constructs between empowerment and service recovery performance.

\section{Reference}

Al-Sabi, S. (2011), The Effect of Empowerment on the Service Recovery Performance of Front Office Agents in Five Star Hotels in Jordan, $\mathrm{PhD}$ thesis, University of Surrey 
Amenumey, E. and Lockwood, A. (2008), "Psychological climate and psychological empowerment: an exploration in a luxury UK hotel group", Tourism and Hospitality Research, Vol. 8 (4), pp. 265-281. https://doi.org/10.1057/thr.2008.34

Ashill, N. J. Carruthers, J. and Krisjanous, J. (2005), "Antecedents and outcomes of service recovery performance in a public health-care environment", Journal of Services Marketing, Vol. 19 (5), pp. 293308. https://doi.org/10.1108/08876040510609916

Ashill, N. J. Rod, M. and Carruthers, J. (2008), "The effect management commitment to service quality on the front line employees' job attitude, turnover intention, service recovery performance in a new public management context", Journal of Strategic Marketing, Vol. 5, pp. 437-462. https://doi.org/10.1080/09652540802480944

Ashill, N. J. Rod, M. Thrikell, P. and Carruthers, J. (2009), "Job resourcefulness, symptoms of burnout and service recovery performance: an examination of call centre front line employees", Journal of Services Marketing, Vol. 23(5), pp. 338-350. https://doi.org/10.1108/08876040910973440

Babakus, E. Yavas, U. Karatepe, O. M. and Avci, T. (2003), "The effect of management commitment to service quality on employees' affective and performance outcomes", Journal of the Academy of Marketing Science, Vol. 31 (3), pp. 272-286. https://doi.org/10.1177/0092070303031003005

Bamford, D. and Xystouri, T. (2005), "A case study of service failure and recovery within an international airline”, Managing Service Quality, Vol. 15 (3), pp. 306-322. https://doi.org/10.1108/09604520510597845

Baron, R. M. and Kenny, D. A. (1986), "The moderator-mediator variable distinction in social psychological research: conceptual, strategic, and statistical considerations", Journal of Personality and Social Psychology, Vol. 51 (6), pp. 1173-1182. https://doi.org/10.1037/0022-3514.51.6.1173

Bell, C. and Zemke, R. E. (1987), "Service breakdown: the road to recovery", Management Review, Vol. 76 (10), pp. 32-35.

Bitner, M. J. Booms, B. H. and Tetreault, M. S. (1990), "The service encounter: diagnosing favourable and unfavourable incidents", Journal of Marketing, Vol. 54 (1), pp. 71-84. https://doi.org/10.1177/002224299005400105

Boshoff, C. (1997), "An experimental study of service recovery options", International Journal of Service Industry Management, Vol. 8 (2), pp. 110-130. https://doi.org/10.1108/09564239710166245

Boshoff, C. and Allen, J. (2000), "The influence of selected antecedents on front line staff's perceptions of service recovery performance", International Journal of Service Industry Management, Vol. 11 (1), pp. 63-90.

Boshoff, C. and Leong, J. (1998), "Empowerment, attribution, apologising as dimensions of service recovery", International Journal of Service Industry Management, Vol. 9 (1), pp. 24-47. https://doi.org/10.1108/09564239810199932

Bowen, D. E. and Johnston, R. (1999), "Internal service recovery: developing a new construct", International Journal of Service Industry Management, Vol. 10 (2), pp. 118-131. https://doi.org/10.1108/09564239910264307

Bowen, D. E. and Lawler, E. E. (1992), "The empowerment of service workers: what, why, how, and when", Sloan Management Review, Vol. 33 (3), pp. 31-39.

Bowen, D. E. and Lawler, E. E. (1995), "Empowering service employees”, Sloan Management Review, Vol. 36 (4), pp. 73-84.

Carson, P. P. Carson, K. D. Eden, W. and Roe, C. W. (1998), "Does empowerment translate action? an examination of service recovery initiatives", Journal of Quality Management, Vol. 13 (1), pp. 133-148. https://doi.org/10.1016/S1084-8568(99)80108-4

Chan, K.W. and Lam, W. (2011), "The trade-off of servicing empowerment on employees' service performance: examining the underlying motivation and workload mechanisms", Journal of the Academy of Marketing Science, Vol. 39 (4), pp. 609-628. https://doi.org/10.1007/s11747-011-0250-9

Chebat, J. C. and Kollias, P. (2000), "The impact of empowerment on customer contact employees' roles in service organizations", Journal of Service Research, Vol. 3 (1), pp. 66-81. https://doi.org/10.1177/109467050031005

Chen, H. and Chen, Y. (2008), "The impact of work redesign and psychological empowerment on organizational commitment in a changing environment: an example from Taiwan's state-owned enterprises", Public Personal Management, Vol. 37, pp. 279-302. https://doi.org/10.1177/009102600803700302

Choi, C.H. Kim, T. Lee, G. and Lee, S.K. (2014), "Testing the stressor-strain-outcome model of customer related social stressors in predicting emotional exhaustion, customer orientation and service recovery performance", International Journal of Hospitality Management, Vol. 36 (1), pp. $272-285$. https://doi.org/10.1016/j.ijhm.2012.09.009

Conger, J. A. and Kanungo, R. N. (1988), "The empowerment process: integrating theory and practice", Academy Management Review, Vol. 13 (3), pp. 471-482. https://doi.org/10.5465/amr.1988.4306983 
Cranage D. A. and Mattila, A. S. (2005), "Service recovery and pre-emptive strategies for service failure: both lead to customer satisfaction and loyalty, but for different reasons", Journal of Hospitality and Leisure Marketing, Vol. 13 (3/4), pp. 161-181. https://doi.org/10.1300/J150v13n03_09

Crawford, A. and Riscinto-Kozub, K. (2010), "The role of the employee: an exploratory study in service recovery satisfaction in the luxury resort industry", Journal of Tourism Insights, Vol. 1(1), 35-44. https://doi.org/10.9707/2328-0824.1003

De Jong, A. and De Ruyter, K. (2004), "Adaptive versus proactive behaviour in service recovery: the role of selfmanaging teams”, Decision Sciences, Vol. 35(3), pp. 457-491. https://doi.org/10.1111/j.0011-7315.2004.02513.

Duffy, J. A. M., Miller, J. M. and Bexley, J. B. (2006), "Banking customers' varied reactions to service recovery strategies", International Journal of Bank Marketing, Vol. 24 (2), pp. 112-132. https://doi.org/10.1108/02652320610649923

Dutta, K. Venkatesh, U. and Parsa, H. G. (2007), "Service failure and recovery strategies in the restaurant", International Journal of Contemporary Hospitality Management, Vol. 19 (5), pp. 351-363. https://doi.org/10.1108/09596110710757526

Enz, C. A. and Siguaw, A. (2000), "Best practice in service quality", Cornell Hotel and Restaurant Administration Quarterly, Vol. 41 (5), pp. 20-29. https://doi.org/10.1177/001088040004100531

Etzel, M. J. and Silverman, B. I. (1981), "A managerial perspective on directions for retail customer dissatisfaction research", Journal of Retailing, Vol. 57 (3), pp. 124-136.

Eylon, D. and Bamberger, P. (2000), "Empowerment cognitions and empowerment acts: recognise the importance of gender", Group and Organization Management, Vol. 25 (4), pp. 354-372. https://doi.org/10.1177/1059601100254003

Ginnodo, B. (1997), The Power of Empowerment, Arlington Heights, Illinois: Pride Publications, Inc

Grönroos, C. (1988), "Service quality: the six criteria of good perceived service", Review of Business, Vol. 9, pp. $10-30$.

Hair, J. F. Jr. Black, W. C. Babin, B. J. Anderson, R. E. and Tatham, R. L. (2010), Multivariate Data Analysis, Prentice-Hall: New Jersey.

Hart, C. W. L. Heskett, J. L. and Sasser Jr, W. E. (1990), “The profitable art of service recovery”, Harvard Business Review, Vol. 68 (4), pp. 148-156.

Hartline, M. D. and Ferrell, O. C. (1996), "The management of customer-contact service employees: an empirical investigation", Journal of Marketing, Vol. 60, pp. 52-70. https://www.jstor.org/stable/1251901

Hayes, B. E. (1994), "How to Measure Empowerment", Quality Progress, Vol. 27 (2), pp.41-6.

Hess R. L. Jr. (2008), "The impact of firm reputation and failure severity on customers' responses to service failures", Journal of Services Marketing, Vol. 22 (5), pp. 385- 398. https://doi.org/10.1108/08876040810889157

Hess, R.L. Jr. Ganesan, R.L.S. and Klein, N.M. (2003), "Service failure and recovery: the impact of relationship factors on customer satisfaction", Journal of the Academy of Marketing Science, Vol. 31 (2), pp. 127-145. https://doi.org/10.1177/0092070302250898

Hocutt, M. A. and Stone, T. H. (1998), "The impact of employee empowerment on the quality of a service recovery effort", Journal of Quality Management, Vol. 3 (1), pp. 117- 132. https://doi.org/10.1016/S10848568(99)80107-2

Johnston, R. and Michel, S. (2008), "Three outcomes of service recovery", International Journal of Operations and Production Management, Vol. 28 (1), pp. 79-99. https://doi.org/10.1108/01443570810841112

Johnson, R. and Redmond, D. (1998), The Art of Empowerment: The Profit and Pain of Employee Involvement, London: Financial Times Management.

Kanter, R. M. (1983), "Frontiers for strategic human resource planning and management", Human Resource Management, Vol. 22 (1/2), pp. 9-21. https://doi.org/10.1002/hrm.3930220104

Kashyap, R. (2001), "The effects of service guarantees on external and internal markets", Academy of Marketing Science Review, Vol.10, pp. 1-19.

Karatepe, O. M. Baradarani, S. Olya, H. G. Ilkhanizadeh, S., and Raoof, A. (2014), "The effect of high performance work practices on critical performance: evidence from the hotel industry", European Journal of Tourism, Hospitality and Recreation, Vol. 5(3), pp. 49-67.

Kelley, S. W. Hoffman, K. D. and Davis, M. A. (1993), "A typology of retail failures and recoveries", Journal of Retailing, Vol. 69 (4), pp. 429-452. https://doi.org/10.1016/0022-4359(93)90016-C

Kim, B. and George, R. T. (2005), "The relationship between leader-member exchange (LMX) and psychological empowerment: a quick casual restaurants employee correlation study", Journal of Hospitality and Tourism Research, Vol. 29 (4), pp. 468-483. https://doi.org/10.1177/1096348005276498

Kim, S.M. and Oh, J.Y. (2012), "Employee emotional response toward healthcare organization's service recovery efforts and its influences on service recovery performance", Service Business, Vol. 6 (3), pp. 297-321. https://doi.org/10.1007/s11628-012-0137-y 
Kirkbir, F. and Cengiz, E. (2007), "Do frontline staff's psychographic attributes and perception of organizational factors affect service recovery performance", Innovative Marketing, Vol. 3 (4), pp. 21-30.

Kildas, A. K. (2001), Employee Empowerment in the European Hotel Industry: Meaning, Process and Culture Relativity, Thela Thesis, Rozengracht, Amsterdam.

Knol, J. and Van Linge, R. (2009), "Innovation behaviour: the effect of structural and psychological empowerment on nurses", Journal of Advanced Nursing, Vol. 65, pp. 359-370. https://doi.org/10.1111/j.1365-2648.2008.04876.x

Kruja, D. Ha, H. Drishti, E. and Oelfke, T. (2016). "Empowerment in the hospitality industry in the United States", Journal of Hospitality Marketing and Management, Vol. 25(1), pp. 25-48. https://doi.org/10.1080/19368623.2015.976696

Lashley, C. (1995), "Towards an Understanding of Employee Empowerment in Hospitality Services", International Journal of Contemporary Hospitality Management, Vol. 7 (1), pp. 27-32. https://doi.org/10.1108/09596119510078207

Lee, M. and Koh, J. (2001), "Is empowerment really a new concept?", The International Journal of Human Resource Management, Vol. 12 (4), pp. 684-695. DOI: 10.1080/713769649

Lewis, B. R., and McCann, P. (2004), "Service failure and recovery: evidence from the hotel industry", International Journal of Contemporary Hospitality Management, Vol. 16 (1), pp. 6-17. https://doi.org/10.1108/09596110410516516

Lytle, R. S. and Timmerman, J. E. (2006), "Service orientation and performance: an organizational perspective", Journal of Services Marketing, Vol. 20 (2), pp. 136-147. https://doi.org/10.1108/08876040610657066

Magnini, V. P. and Ford, J. B. (2004), "Service failure recovery in china", International Journal of Contemporary Hospitality Management, Vol. 16 (5), pp. 279-286. https://doi.org/10.1108/09596110410540249

Masdek, N. Aziz, Y. and Awang, K. W. (2011), "Potential antecedents and outcomes of frontline employees' service recovery performance", International Journal of Economics and Management, Vol. 5(1), pp. 114 139.

Maxham, J .G. (2001), "Service recovery's influence on consumer satisfaction, positive word-of-mouth, and purchase intentions", Journal of Business Research, Vol. 54 (1), pp. 11-24. https://doi.org/10.1016/S01482963(00)00114-4

Melhem, Y. (2004), “The antecedents of customer-contact employees' empowerment", Employees Relations, Vol. 26 (1), pp. 72-93. https://doi.org/10.1108/01425450410506913

Miller, J. L. Craighead, C. W. and Karwan, K. R. (2000), "Service recovery: a framework and empirical investigation", Journal of Operations Management, Vol. 18, pp. 387-400. https://doi.org/10.1016/S02726963(00)00032-2

Mills, P. K. and Ungson, G. R. (2003), "Reassessing the limits of structural empowerment: organisational constitution and trust as control", Academy of Management Review, Vol. 28 (1), pp. 143-153. https://www.jstor.org/stable/30040694

Ministry of Tourism and Antiquities Jordan. (2019). "Statistics". Retrieved June 2, 2020, from https://www.mota.gov.jo/Contents/stat2019Ar.aspx

Rafiq, M. and Ahmed, P. K. (1998), "A customer-oriented framework for empowering service employees", Journal of Services Marketing, Vol. 12 (5), pp. 279-396. https://doi.org/10.1108/08876049810235423

Randolph, W. A. (1995), "Navigating the journey to empowerment", Organisational Dynamics, Vol. 23 (4), pp. 19-32. https://doi.org/10.1016/0090-2616(95)90014-4

Randolph, W. A. and Sashkin, M. (2002), "Can organizational empowerment work in multinational settings?", Academy of Management Executive, Vol. 16 (1), pp. 102-115. https://doi.org/10.5465/ame.2002.6640205

Savery, L. K. and Luks, J. A. (2001), "The relationship between empowerment, job satisfaction and reported stress levels: some Australian evidence", Leadership and Organization Development Journal, Vol. 22 (3), pp. 97 104. https://doi.org/10.1108/01437730110389247

Schumacher, S. and Komppula, R. (2016), "A case study on service recovery: Frontline employees' perspectives and the role of empowerment", European Journal of Tourism, Hospitality and Recreation, Vol.7 (2), pp. 117-127. https://doi.org/10.1515/ejthr-2016-0014

Seawright, K. K. DeTienne, K. B. Bernhisel, M. P. and Larson, C. L. (2008), “An empirical examination of service recovery design", Marketing Intelligence and Planning, Vol. 26 (3), pp. 253-274. https://doi.org/10.1108/02634500810871320

Speier, C. Whipple, J.M., Closs, D.J. and Voss, M.D. (2011), "Global supply chain design considerations: mitigating product safety and security risks", Journal of Operations Management, Vol. 29 (7/8), pp. 721736. https://doi.org/10.1016/j.jom.2011.06.003

Spreitzer, G. M. (1995), "Psychological empowerment in the workplace: dimensions, measurement, and validation", Academy of Management Journal, Vol. 38 (5), PP. 1442-1465. http://dx.doi.org/10.2307/256865 
Spreitzer, G. M. (1996), "Social structural characteristics of psychological empowerment", Academy of Management Journal, Vol. 39 (2), pp. 483-504. https://doi.org/10.2307/256789

Sood, A. (2007), Empowerment Effects Across Cultures, PhD thesis, Aston University.

Sparks, B. A. (2001), Managing Service Failure through Recovery: In Kanadampully, J., Mok, C. and Sparks, B. A. Service Quality Management in Hospitality Tourism and Leisure, The Haworth Hospitality press, an imprint of The Haworth Press, Inc, pp. 193-221.

Sparks, B. A. Bradley, G. L. and Callan, V. J. (1997), "The impact of staff empowerment and communication style on customer evaluations: the special case of service failure", Psychology and Marketing, Vol. 14 (5), pp. 475-493. https://doi.org/10.1002/(SICI)1520-6793(199708)14:5<475::AID-MAR3>3.0.CO;2-5

Tax, S. S. and Brown, S. W. (1998), "Recovering and learning from service failure", Sloan Management Review, Vol. 40(1), pp. 75-88.

Uzunbacak, H.H. (2015), "The Impact of employee empowerment on innovation: a survey on Isparta and Burdur organised industrial zones", Journal of International Social Research, Vol. 8 (37), pp. 977-989. DOI: $10.17719 /$ jisr.20153710663

Yavas, U. Karatepe, O. M. and Babakus, E. (2010), "Relative Efficacy of Organizational Support and Personality Traits in Predicting Service Recovery and Job Performances: A Study of Frontline Employees in Turkey", Tourism Review, Vol.65(3), pp. 70-83. https://doi.org/10.1108/16605371011083530

Yavas, U. Karatepe, O. M., Avci, T. and Tekinkus, M. (2003), "Antecedents and outcomes of service recovery performance: An empirical study of frontline employees in Turkish banks", International Journal of Bank Marketing, 21(5), 255-265. https://doi.org/10.1108/02652320310488439

Yee, R.W. Young, A.C. and Cheng, T.E. (2010), "An empirical study of employee loyalty, service quality and firm performance in the service industry", International Journal of Production Economics, Vol. 124 (1), pp. 109-120. https://doi.org/10.1016/j.ijpe.2009.10.015

Zhang, M. and Geng, R. (2019), "Empowerment in service recovery: the role of self-regulation process of frontline employee", Management Decision,https://doi.org/10.1108/MD-10-2018-1073

Zeithaml, V. A. Berry, L. L. and Parasuraman, A. (1988), "Communication and control process in the delivery of service quality", Journal of Marketing, Vol. 52 (April), pp. 35-48. https://www.jstor.org/stable/1251263

Zemke, R. (1994), "Service recovery", Executive Excellence, Vol. 18, pp. 17-18.

Zemke, K. and Bell, C. (1990), "Service recovery: doing right the second time", Training, Vol. 27 (6), pp. 42-8. 